\title{
Personal Profile of the Leader: Explanatory Factor in the Practice of Business Intelligence
}

\author{
Hourenatou $^{1} \&$ Tsapi Victor ${ }^{1}$ \\ ${ }^{1}$ Department of Management, Faculty of Economics and Management, University of Ngaoundere, Cameroon \\ Correspondence: Hourenatou, Department of Management, Faculty of Economics and Management, University \\ of Ngaoundere, Cameroon. E-mail: boubakariake@yahoo.fr
}

Received: February 18, 2014

Accepted: May 12, 2014

Online Published: June 22, 2014

doi:10.5539/ijbm.v9n7p39

URL: http://dx.doi.org/10.5539/ijbm.v9n7p39

\begin{abstract}
With globalization, the discovery of new opportunities and their realization can only be successful if companies have an adequate field of vision. They must have the ability to collect, store, distribute and analyze information especially relating to the status and trends of socio-economic environment. Hence the development of business intelligence structures within companies. Almost all developed countries have realized the importance of this activity and have developed intelligence. Africa in general and Cameroon in particular, knowledge and practice of business intelligence is very low both at market and state level. The business leader is considered as the main actor of this practice, the empirical study of 62 companies in Cameroon not only to highlight the characteristics of the practice of business intelligence but also to analyze the influence of personal profile the leader of this practice.
\end{abstract}

Keywords: external environment, strategic information, business intelligence, personal profile of the leader

\section{Introduction}

Organizations nowadays operate in an increasingly complex environment characterized by the increase in opportunities and multiplication of risks and uncertainties. In Cameroon, this transformation is reflected among others by a high number of business closures in both the private and the public sector. Government and public enterprises are struggling to breathe fresh life into the economy. This explains why hopes rest on private businesses whether large, medium or small to create new jobs and stimulate economic growth. Kombou (2001) noted that the Cameroonian companies were created and developed in the context of market protectionism, where state power has played a central role in their emergence and their development choices. The divestiture materialized by several privatization, price liberalization, removal of subsidies, and liberalization of economic sectors leads to increase competition. This competition has heightened with the removal of barriers and open competition. It is important for companies to have the capacity and resources to survive and prosper in this global competition. Today, they must not only control their internal environment but also be open to their external environment to turn threats into opportunities. The discovery of these new opportunities and their realization can only succeed if the Cameroonian companies have an adequate field of vision, that is to say the ability to collect, store, distribute and analyze information especially on the status and trends of socio-economic environment in order to help managers in their decision making. Thus, the concept of business intelligence is the tool response to this strategic willingness to adapt to ensure a rapid response at the right time. Business intelligence can be defined as an informational process by which an organization listens to its environment to decide and act quickly.

In Africa, the practical knowledge of the function of strategic intelligence remains limited both in terms of market and state level. Ouattara (1997), in his research concludes that the role of information is reduced by African leaders. For Ngongang (2013), the introduction of IT improves the quality of information, which allows companies to gain the confidence of investors. However, in recent years, Africa made efforts to secure the information society. It was created the African Organization of Competitive Intelligence and sopel ${ }^{1}$ firm in partnership with the World Bank have since 2000 been organizing meetings on economic intelligence, business intelligence and the development of new technologies in Africa. Each year, the meeting brings together experts in business intelligence, economic intelligence, political and economic decision makers, international organizations and the civil society. 
In Cameroon, the penetration of new information technology in the Cameroonian companies remains low and is less than $50 \%$ (INS/RGE, 2009). However, this situation may soon improve with the observed strong competition in the telecommunications sector and lowering significant and consistent IT costs. For Sone Mbassi (2012), although modest, the level of ownership of IT Cameroon has improved markedly over the last decade. Unfortunately, the practice of business intelligence remain very weak in African companies. It appears from the work of the firm Gweth Marshall (2008) in the CEMAC countries, the penetration rate of the activity of business intelligence is less than $2.5 \%$. This makes us aware of the delay of the countries of Central Africa in general and Cameroon in particular, compared with Western countries in terms of business intelligence. This delay may be due in part to the leader of the company, because according to El Mabrouki (2007), business intelligence is a simple functional personalized services to decision makers. In addition, the Cameroonian economic fabric is formed mainly by SMEs which are structures in which the leader plays a key role. It is then necessary to consider the role of the leader, a central figure of strategic intelligence.

The aim of our research is to highlight the influence of the personal profile of the leader on the practice of strategic intelligence. To achieve this, we will first focus on the concepts of business intelligence and personal profile of the leader. Then we will present the methodology and finally, the results of our study.

\section{Literature}

\subsection{The Concept of Business Intelligence}

The concept of business intelligence emerged in the sixties with the work of Aguilar (1967) and has attracted the interest of researchers in many countries, including emerging economies, as well as practitioners (Kriaa-Medhaffer, 2006). For Aguilar (1967) pioneered research on intelligence, business intelligence is to enter information about events and relationships taking place in the external business environment, information so knowledge is likely to help the management team in its strategic choices about the future of companies. Lesca (1994) defines business intelligence as a proactive information process by which the company listens anticipatory (or prospective) early signals of its socio-economic environment in order to open up the creative opportunities and reduce risks related to its uncertainty. For Pateyron (1998), Business Intelligence is seeking information through constant vigilance and continuous monitoring of the environment for strategic aims. Lesca and Castagnos (2000) define business intelligence as "the voluntary process by which the company (or part thereof) stalking and assimilates information regarding anticipatory changes in its socio-economic environment in the aim to create business opportunities, reduce risks associated with uncertainty and act quickly at the right time. Without entering into the debate on these definitions, we can retain that business intelligence is a collective and proactive information process by which members of the organization begin proactively listening to their external environment in order to detect and anticipate changes and enable leaders to better manage the business. It is therefore in a process upstream of the broader strategic decision-making within the company (Isaac, 2003). This process can be enhanced through the following simplified representation proposed by Lafaye (2004).

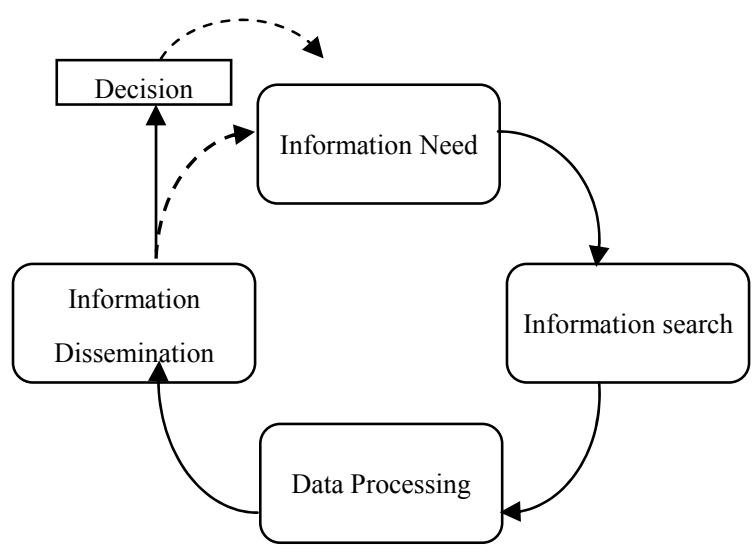

Figure 1. The process of business intelligence by Lafaye (2004)

Business intelligence is a sub strategic information system that is recognized as a device to know the business environment and anticipate changes (Lesca, 2003). It is a tool full of information and ongoing understanding of market realities, technical competitors, their intentions and capabilities. Business intelligence refers to both the 
market information (technology, competitors, suppliers, customers) and that related to the business environment in general (economic, legal environment, political and socio-cultural). It is a generic term that includes several specific types of watches such as technological, competitive intelligence, business intelligence, and environmental monitoring.

\subsection{The Personal Profile of the Leader and Practice of Business Intelligence}

Since the work of March and Simon (1964), personal characteristics of the leader, including variables such as age, religion, education, past experience and family history, but also personal values, criteria moral and temperamental nature, have gained importance as indicative of the performance of the company. The profile of the leader, with different dimensions it encompasses, representations and beliefs that result, would inform the logical action of this agent, and would have an impact on some of its behavior. Thus, Amabile et al. (2011) clarify the role of the leader in the practice of business intelligence. According to them, the leader puts into perspective his influence on the direction of monitoring activities, the definition of informational targets sought as well as the level of internal dissemination of such information. Our analysis will focus primarily on the variables that appear to be more significant and, to our knowledge, have never been explored in our context. This is the age, gender, educational level and experience of the leader.

\subsubsection{Age of Leader and Practice of Business Intelligence}

According to Niyungeko (1993), at different ages reflect different motivations, and therefore, attitudes, behaviors and different acts. Age is therefore a key factor in the different strategic choices of the leader. For Hambrick and Mason (1984), age is generally associated with a more conservative behavior assumed to have a negative impact on the performance of the company for three reasons. The first reason assumes that an older leader is normally less inclined to adopt innovative behavior or to join a new idea. In the same way, Kets de Vries (2002) believes that mature has weaknesses (physical, psychological) that can strongly influence the leader, hence the importance to see young people at the top of the hierarchy. The second reason relates to the fact that the old leader is attached to a certain organizational status quo. Finally, the objectives of workplace and employee safety create a more prudent behavior. Business intelligence is a practice that requires a strong commitment from the leader. Its aim is to increase business responsiveness so that they can adapt to an environment more complex. The leader must not only have the desire, energy, creative spirit and innovative but also the ability to sensitize and mobilize other members of the company. This behavior is associated with young business leaders.

\section{Hypothesis 1: Business Intelligence is more practiced by the younger leaders than older leaders.}

\subsubsection{Gender and Practice of Business Intelligence}

The term "gender" refers to biological differences between men and women (Morley, 2001). According to this author, the social environment and socialization processes lead men and women into different roles. Thus, by nature, man is supposed to be strong, leader, ambitious, confident and eager to material success, while women are supposed to be loving, compassionate, gentle, modest and interested in the quality of life. Schopenhauer (2005) believes that the only aspect of the woman reveals that she is not for the great work of the intelligence or the major physical work. In Africa, women are relegated to the background. However, in Cameroon, in competition at various positions in the public sector, the State recommended for identical profiles, the priority of gender (Feudjo \& Tchankam, 2007). Despite multiple development programs of equity between men and women, the rate of integration of women in working life and especially in business remains very low. Kombou and Feudjo (2007) found that leaders Cameroonian companies are struggling to accept women as direct collaborators or those to positions of significant responsibility. For these authors, many prejudices surrounding the work of women in African societies in general. It is therefore plausible that the man and woman cannot run a business in the same way. However, the literature shows that women entrepreneurs encourage participation and teamwork, sharing of power and information and they are also adept to stimulate, develop and motivate their employees to work (Mione et al., 2002). These behaviors should predispose to be vigilant, to react quickly to changes in the environment and have the spirit of innovation. The gender factor then appears to have an influence on the practice of business intelligence in firms.

\section{Hypothesis 2: Business Intelligence is more practiced by women than by men.}

\subsubsection{Educational Level and Practice of Business Intelligence}

The education officer is another determinant of the practice of business intelligence in firms. Robidoux and Garnier (1973), showed that the higher the education level of the manager, the higher the rate of growth of the company. Likewise, these authors point out that the contractor has more advanced studies, the more he is able to solve the complex problems of business and its technical or administrative knowledge or is able to acquire easily. 
Many other empirical studies find that the level of education of the leader has a positive impact on the company (Almus, 2002; Julien, 2000; Hall, 1995). This impact can be justified by the fact that education improves the skills and abilities of individuals (Montgomery et al., 2005). Theoretically, one might think that education would have a positive influence on the practice of business intelligence. However, the work of Ramangalahy et al. (1996) goes in the opposite direction. For these authors, among the personal characteristics of the leader, only the level of education is crucial. More specifically, the more the executive are educated the less they give importance to business intelligence and solicited diverse sources of information. Rather, we agree with the first vision because we assume that leaders with a high level of education have the capacity to interest and engage in business intelligence.

\section{Hypothesis 3: Business Intelligence is practiced by leaders who have a high level of those with a low level of education attainment.}

\subsubsection{Experience and Practice of Business Intelligence}

There are a number of studies on the relationship between the experience of the manager and business intelligence activities, and this, both at the level of the implementation of this business intelligence and its intensity. Two schools of thought lingered on the level of experience of the person who monitors the environment, considered as a feature also likely to influence the practices of business intelligence. The first school of thought supports the hypothesis that people experience trying to collect less information because they can call routines and proven solutions to their problems (Carson, 1985). In the same way, Kaish and Gilad (1991) found that most owner-managers of SMEs had experience; their business intelligence was less intensive. For Cooper, Folta and Woo (1995), unless a contractor has experience in entrepreneurship, the more it will try to gather information about its environment. Proponents of the second school of thought (Taylor, 1975; Julien, 1994; Menif, 2005) hypothesize that those who have more experience looking for more to collect information because they have patterns more developed thinking. On the contrary, those who have no experience not extensively scrutinize the environment because they do not know what to look for and where to look. Based on analyzes of the exploratory study, Cameroon experienced leaders gave great importance to research information about the external environment. This brings us to rally to the second current by asking the following hypothesis:

Hypothesis 4: Business intelligence is practiced by executives with longer experience than those with less experience.

\section{Methodology}

In this study, we adopted a hypothetical deductive approach. We used at first a theoretical analysis to identify not only the concepts, but also to analyze the influence of the personal profile of the leader on the practice of strategic intelligence. In a second step, using a questionnaire, we collected information from a sample of our population. It was administered in "face to face" with the leader or corporate executives who can provide us with information on the monitoring activity. Although not having timely and reliable data that can enable the creation of a frame, companies were selected based on the so-called "rational choice" empirical method. Thus, any respondent is part of the sample, since it consists of 10 to 49 employees for small businesses, with 50 to 199 employees for the average business and 200 and more for big business. Following this logic, we identified 240 companies located in Douala, Yaounde, Bafoussam and Garoua. Out of these 240 companies of our sampling frame, we establish contact with 78 of them. Overall, after survey, 62 questionnaires were usable, 62 firms included in our final sample. This sample consists of 25 service companies, 22 industrial and 15 commercial enterprises. The information collected through these questionnaires have undergone statistical analyzes using SPSS. After performing a principal component analysis on the items of the practice of business intelligence, we used analysis of variance and comparison of means test to test our hypotheses.

\section{Measurement of Variables}

\subsection{The Measurement of the Practice of Business Intelligence in a Firm}

According to the writings listed, there are three main ways to operationalize the practice of business intelligence. The first based on the information frequency that is received. The second based on the interest shown in the information and the third related to the number of hours devoted to monitoring activities. The latter is undoubtedly the worst since it is well recognized that individuals have difficulty to quantify the number of hours the time spent in an activity, especially that monitoring activities are often fragmented. This is also the conclusion arrived by Farh et al. (1984), which verified the validity of these three operationalization of the intensity of monitoring activities. We were inspired by the work of Hambrick (1982), Daft et al. (1988), Choo (1993) and Audet (1998) to develop our own measures of the practice of business intelligence. We selected six 
items that reflect the intensity of strategic intelligence in firms. We used a Likert scale with five points follows: Very Low, Low, Medium, High and Very High.

Table 1. Measuring range of the practice of business intelligence

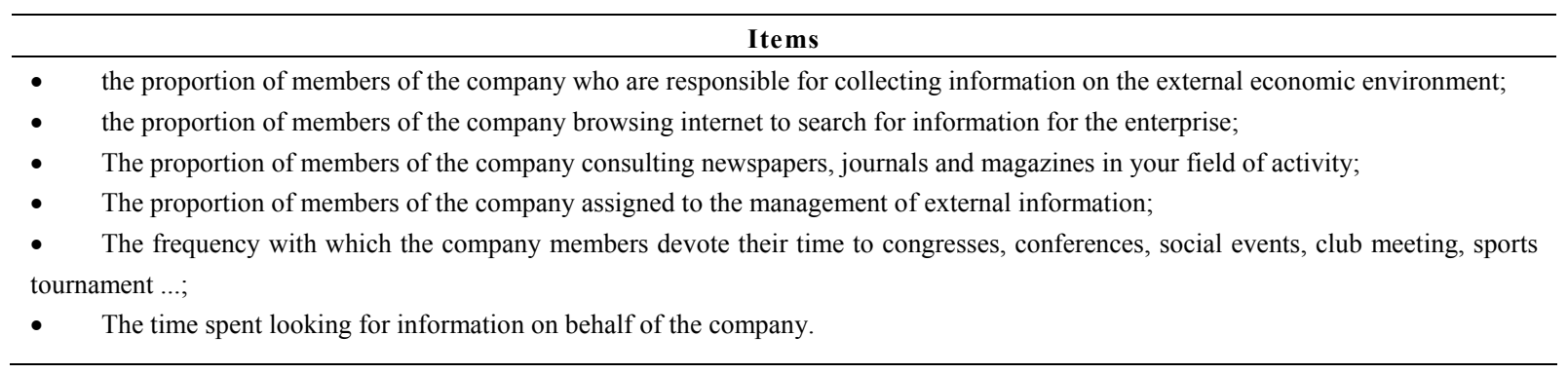

\subsection{Measuring Elements of Personal Profile Manager}

An age leader was measured based on the number of years since birth. This variable consists of five categories: 1) less than 30 years, 2) 30 to 40 years, 3) 41 to 50 years 4) 51 to 60 years, 5) 60 years and above.

The sex of the leader was apprehended through a dichotomous variable that takes the value 1 if the leader is a woman and 0 if it is a man.

The level of education was measured by four methods. 1) Self-taught, 2) Primary 3) Secondary, 4) Superior.

The experience of the leader was measured through the number of years spent at the head of the company. 1) Less than 3 years, 2) 3-6 years, 3) 7-10 years 4) 11 years and older.

\section{Analysis and Results}

\subsection{Characterization of Respondents and Companies}

The results show a good representation of SMEs (75.8\%) then $46.8 \%$ of small firms and $29 \%$ of medium-sized enterprises. Only $24.2 \%$ of our samples are large companies. The majority of respondents in the sample were male $(74.2 \%)$. Only $25.8 \%$ of managers or executives are women. This could be explained among other sociological distribution of male and female roles whose roots are probably related to the customs, traditions, religion ... We note that the majority of leaders an age that is in the range of 30 to 50 years $(67.7 \%)$. Those aged 51 and over as a percentage of $16.1 \%$. The distribution of respondents by age shows that a significant percentage of managers $(62.9 \%)$ are in their position for more than seven years and only $37.1 \%$ had more than 6 years in the firm. These individuals would therefore have acquired sufficient experience to manage their business. It appears that 47 respondents, $75.8 \%$ are with a tertiary education. As for the other respondents, they are rich or a diploma of secondary education (10 respondents, or $16.1 \%$ ) or a degree in primary education (three respondents, or $4.8 \%$ ). However, we also have the presence of two respondents (3.2\%) with no qualifications. Failure to possess any degree does not mean that this person does not know to run a business. His presence within the company and sometimes even an important function may be due, apart from the equity of the company, the existence of a management policy appropriate career. Under these conditions, it is not surprising that the general manager says he began his career as a trader without prior training. Ultimately, leaders and responsible marketing, sales and technical in our sample have a relatively high level of education. Such education is a plus point to record the account of the quality of data collected.

\subsection{Embryonic Practical Business Intelligence in Cameroon Companies}

In companies, the concept of business intelligence is ignored by many leaders. Some confuse it with espionage and others are limited to competitive intelligence. The results of sorting flat show that $46.8 \%$ of respondents admit to having a service assigned to the management of information. In these services, no company in our sample has a specific cell of business intelligence. $14.5 \%$ have assigned responsibility for the management of information. These officials are called managers of information systems, IT managers, CEOs and heads of IT cells. Thus, it appears that $75.8 \%$ of respondents indicated that the proportion of members assigned to the collection of information is low (30.6\% very low and $45.2 \%$ low), but only $3.2 \%$ believe that Internet tool is used to search for information about the external environment. We find that the proportion of people regularly checking newspapers, presses and those assigned to the management of information is very low (8.1\%). Regarding the proportion attending conventions, conferences, club meeting... members, only $12.9 \%$ of 
respondents believe that this proportion is high ( $9.7 \%$ higher and 3.2\% very high). However, we find that $79 \%$ of respondents believe that the time spent searching for information from the environment is very low $(27.4 \%$ very low and $51.6 \%$ low). The minimum score on these items is 6 and maximum of 30, with an average of 18 . The calculated average is 15.93 . We then find that $77.4 \%$ of companies have a practice of low level of business intelligence and only $22.6 \%$ have a high level.

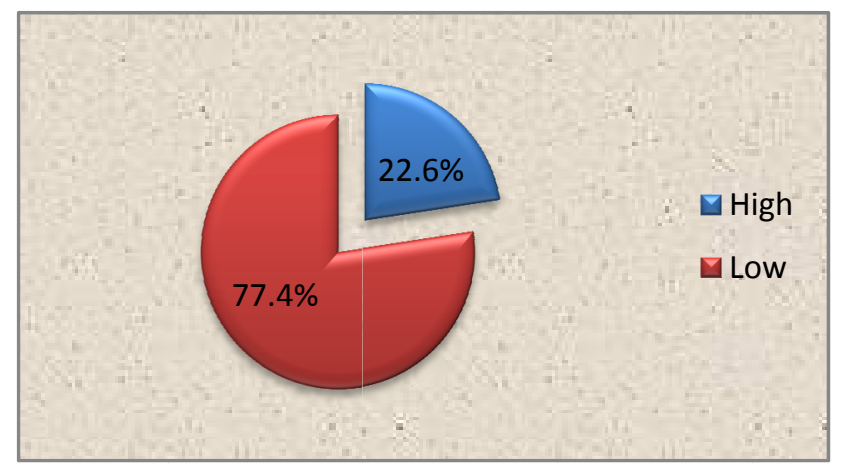

Figure 2. Level of practice of business intelligence in Cameroonian companies

5.3 Testing Hypotheses about the Relationship between the Elements of the Personal Profile of the Leader and the Practice of Business Intelligence

To test our hypotheses, a comparison of means test and ANOVA one factor were performed on the variables apprehending the personal profile of the leader and the practice of business intelligence.

\subsubsection{Hypothesis Test between the Age of the Leader and the Practice of Business Intelligence}

An analysis of variance was performed one factor between the age of the leader and the practice of business intelligence. The results are presented above.

Table 2. Test of homogeneity of variances practice of business intelligence

\begin{tabular}{llll}
\hline Statistics Levene & dd11 & dd12 & Signification \\
\hline .890 & 4 & 57 & .476 \\
\hline
\end{tabular}

Levene's test was significant $(0.476>0.05)$. The assumption of homogeneity of the sample is accepted.

Table 3. ANOVA one factor Practice of business intelligence

\begin{tabular}{llllll}
\hline & Sum of squares & ddl & Mean square & F & Signification \\
\hline Inter-groups & 1061,322 & 4 & 265,331 & 3,740 &, 009 \\
Intra-groups & 4044,178 & 57 & 70,950 & & \\
Total & 5105,500 & 61 & & & \\
\hline
\end{tabular}

The t-test gives a value of $F=3.740$ with $p=0.009$. The $p$-value is below the threshold of 0.05 , we find a significant difference between the means. Age leader actually has an influence on the practice of the day. Thus, our first hypothesis is validated. However, at this stage we cannot say what age affects sleep. Therefore, we realize the multiple comparison test or post hoc test. 
Table 4. Post hoc tests homogeneous subsets practice of business intelligence Duncan

\begin{tabular}{llll}
\hline Age & $\mathrm{N}$ & \multicolumn{2}{l}{ subsets for alpha $=0.05$} \\
\cline { 3 - 4 } & & 1 & 2 \\
\hline 61 years and over & 2 & 40.5000 & 52.8571 \\
51 à 60 years & 7 & & 58.8077 \\
30 à 40 years & 26 & & 60.3529 \\
41 à 50 years & 17 & & 62.1000 \\
Less than 30 years & 10 & 1.000 & .088 \\
Signification & & & \\
\hline
\end{tabular}

Duncan's test showed that having at least 60 years permits for the practice of business intelligence. This practice is observed for those under 30 . The average practice of strategic intelligence for this class of leaders is at 62.1000 against 60.3529 to those under the age of 41 to 50 years. Those with 51 to 60 years recorded 52.8571 and those 30 to 40 years recorded 58.8077. In contrast, those with 61 years and older report that 40.5000 and are presented in the table as those who do not practice business intelligence.

5.3.2 Hypothesis Test between Gender of the Leader and the Practice of Business Intelligence

A test for comparison of means was made between sex variables and practice leader of business intelligence.

Table 5. Group statistics

\begin{tabular}{llllll}
\hline & Gender & $\mathrm{N}$ & Average & Gap-type & Average standard error \\
\hline \multirow{2}{*}{ Business intelligence } & Female & 16 & 55.1250 & 7.80491 & 1.95123 \\
& Male & 46 & 59.6739 & 9.36436 & 1.38070 \\
\hline
\end{tabular}

After reading this, it appears that male individuals are those who practice the business intelligence. They get an average 59.67 while their female counterparts get only 55.13. The difference between the two averages is given in the table and the third is -4.55 .

Table 6. Test of independent samples

\begin{tabular}{llllll}
\hline & & Levene's test of equality of variances & \multicolumn{2}{c}{ T-test for equality of average } \\
\cline { 3 - 6 } & & $\mathrm{F}$ & $\mathrm{S}$ Sig. & $\mathrm{t}$ & $\mathrm{d}$ \\
\hline Business & Hypothesis of equal variances & .733 & .395 & -1.741 & 60 \\
intelligence & Hypothesis unequal variances & & & -1.903 & 31.176 \\
\hline
\end{tabular}

Levene's test whose results are presented in the table above is significant and shows that the variances are homogeneous $(\mathrm{p}=0.395>0.05)$. The hypothesis of homogeneity of the sample is accepted.

Table 7a. Test of independent samples

\begin{tabular}{lllll}
\hline & & \multicolumn{2}{l}{ T-test for equality of averages } \\
\cline { 3 - 5 } & & Sig. (bilatéral) & Average difference & Gap-type difference \\
\hline Business & Hypothesis of equal variances & .087 & -4.54891 & 2.61212 \\
intelligence & Hypothesis unequal variances & .066 & -4.54891 & 2.39032 \\
\hline
\end{tabular}

Table $7 \mathrm{~b}$. Test of independent samples

\begin{tabular}{llll}
\hline & & \multicolumn{2}{l}{ T-test for equality of averages } \\
\cline { 3 - 4 } & & $\begin{array}{l}\text { 95\% confidence interval of the difference } \\
\text { Inferior }\end{array}$ & Superior \\
\hline Business & Hypothesis of equal variances & -9.77393 & .67611 \\
intelligence & Hypothesis unequal variances & -9.42288 & .32506 \\
\hline
\end{tabular}


When reading this table, it appears that the p-value of 0.087 is greater than 0.05 . This value is high, we conclude that the average are not significantly different. Our second hypothesis is rejected. The sex was not a significant influence on the practice of business intelligence.

\subsubsection{Hypothesis Test between Educational Level and the Practice of Business Intelligence}

The analysis of variance one factor between education officer and the practice of strategic intelligence gives us the following results.

Table 8. Test of homogeneity of variances practice of business intelligence

\begin{tabular}{llll}
\hline Statistics Levene & ddl1 & dd12 & Signification \\
\hline .845 & 3 & 58 & .475 \\
\hline
\end{tabular}

Levene's test was significant $(0.475>0.05)$. The assumption of homogeneity of the sample is accepted.

Table 9. ANOVA one factor Practice of business intelligence

\begin{tabular}{llllll}
\hline & Sum of squares & ddl & Mean square & F & Signification \\
\hline Inter-groups & 848,327 & 3 & 282.776 & 3,853 & .014 \\
Intra-groups & 4257,173 & 58 & 73.400 & & \\
Total & 5105,500 & 61 & & & \\
\hline
\end{tabular}

The t-test gives a value of $F=3.853$ with $p=0.014$. The $p$-value is below the threshold of 0.05 , we find a significant difference between the means. The education officer has an influence on the practice of business intelligence. The hypothesis is validated. However, at this stage we cannot say what level of education influences business intelligence. Therefore, we realize the multiple comparison test or post hoc test.

Table 10. Post hoc tests homogeneous subsets practice of business intelligence duncan

\begin{tabular}{llll}
\hline \multirow{2}{*}{ Level of education } & $\mathrm{N}$ & \multicolumn{2}{l}{ subsets for alpha $=0.05$} \\
\cline { 3 - 4 } autodidact & 2 & 40.5000 & 2 \\
Primary & 3 & 51.6667 & 51.6667 \\
Secondary & 10 & & 58.9000 \\
Superior & 47 & & 59.6170 \\
Signification & & .064 & .211 \\
\hline
\end{tabular}

Duncan's test showed that having a higher level allows more practice business intelligence. The average practice before this category of leaders is 59.6170 . The leaders had a secondary report that 58.9000 and just come after those of the higher level. However, an intermediate behavior was recorded for those with a primary school education. They show no significant difference with the leaders of each group they belong to both groups. The autodidact only record 40.5000 and are presented in the table as those who do not practice the day before. We conclude that at the primary level, leaders take note of the interest of the practice of business intelligence.

\subsubsection{Hypothesis Test between the Experience of the Manager and the Practice of Business Intelligence}

The results of the analysis of variance between the experience of the manager and the practice of business intelligence are presented below. 
Table 11. Test of homogeneity of variances practice of business intelligence

\begin{tabular}{llll}
\hline Statistics Levene & dd11 & dd12 & Signification \\
\hline 2,036 & 3 & 58 & .119 \\
\hline
\end{tabular}

Table 12. ANOVA one factor practice of business intelligence

\begin{tabular}{llllll}
\hline & Sum of squares & ddl & Mean square & F & Signification \\
\hline Inter-groups & 422,443 & 3 & 140.814 & 1.744 & .168 \\
Intra-groups & 4683,057 & 58 & 80.742 & & \\
Total & 5105,500 & 61 & & & \\
\hline
\end{tabular}

Levene's test with a value of 2.036 and a probability of significance of 0.119 is significant $(0.119>0.05)$. The assumption of homogeneity of the sample is accepted. However, analysis of variance gives us $F=1.744$ with a probability of significance $p=0.168$. The probability of significance is greater than the significance level of 0.05 ; we conclude that there is no significant difference between the means. The experience does not have an influence on the practice of the business intelligence. In other words, the practice of business intelligence by leaders is not always the number of years spent at the head of the company. A new leader under 3 years of experience can practice as an old standby which has more than 11 years of experience.

\section{Conclusion}

With globalization and the need for competitiveness, business intelligence is not only practical, it is a necessity for any company wanting to ensure its sustainability business. Search conducted with 62 companies Cameroon show that the practice of strategic intelligence is still in its embryonic. It is more informal than formal, and is not integrated into the general culture of the company. Through a literature review, we identified four factors which may have an influence on the practice. This is age, sex, level of education and experience of the leader. Our results show that two of the four factors have an influence on the practice of business intelligence. This is the age and level of education of the leader.

According to the results, being young significantly influences the practice of business intelligence. This allows us to go in the same direction as Skander Rim (2004) to say that a young leader could be more flexible in innovation, new practices and tools that old and older leader. However, it would be more attached to traditional methods and should be continually trained to handle all that is new in management and getting used to.

The level of education has an influence on the practice of business intelligence. Thus, the higher the officer has a high level of education, the more practice the business intelligence. These results are contrary to those of Ramangalahy et al. (2006) but in the same direction as those of Robidoux and Garnier (1973) and Montgomery and al. (2005) which show that the manager with a high level of education is able to solve complex problems as education improves their skills and abilities. Then it is logical to find that the level of education of the leader has an impact on the practice of business intelligence.

Our results indicate that there is no relationship between the experience of the manager and the practice of business intelligence. They go in the same direction as Ramangalahy et al. (1996) which culminated in the fact that the experience of the leader is not a determinant of practical technology watch. Our results are in contradiction with the results of some authors who believe that career experience can have a positive or negative influence on business intelligence (O'Reilly, 1982; Cooper et al., 1995; Kaish \& Gilad, 1991; Raymond et al., 2005). The lack of relationship between the two concepts can have many explanations. We measured the experience by the number of year as this may be a fundamental right. For Myers (1983), it is not everyone who worked for many years in organizations that could provide work watchman. In fact, over the majority of our sample managers $(62.9 \%)$ have more than 7 years in the business and $37.1 \%$ are under the age of 7 . This allows us to go in the same direction as Skander Rim (2004) to say that a young leader could be more flexible in innovation, new practices and tools that old and older leader. However, it would be more attached to traditional methods and should be continually trained to handle all that is new in management and getting used to.

Regarding gender, the results indicate that there is no association between this variable and the practice of strategic intelligence. This confirms the work of Mead (1963) who believes that personality cannot be explained by biological characters, but by the particular cultural model for a society that determines the education, training 
individuals and their integration into the life active and professional. Thus, the fact of being a man or woman has no influence on the practice of business intelligence.

Our results provide some clues to explain the reasons that could explain not only the embryonic state of the practice of business intelligence but also the central role of the leader in this practice. Our research is limited to the extent that we focus on the manager irrespective of factors related to the company. The analysis of factors related to the company and the interaction of both factors (and business manager) could complete this study.

\section{References}

Aguilar, F. J. (1967). Scanning the business environment (p. 239). Mac Millan: Wiley.

Almus, M. (2002). What characterizes a fast-growing firm. Applied Economics, 34, 1497-1508. http://dx.doi.org/10.1080/00036840110105010

Amabile, S., Laghzaoui, S., \& Boudrandi, S. (2011). Pratiques de veille stratégique par les PME exportatrices. Revue Management et Avenir.

Audet, J. (1998). La veille stratégique chez les PME québécoises : une étude de cas par comparaisons inter-sites. Thèse de Doctorat, Université Laval, Sainte-Foy, Québec.

Carson, R. (1985). School superintendents: career and performance. Calumbia, OH, Merrill.

Choo, C. W. (1993). Environmental Scanning: acquisition and use of information by chief executive officers in the Canadian Telecommunications Industry. University of Toronto.

Cooper, A., Folta, T., \& Woo. (1995). Entrepreneurial information search. Journal of Business Venturing, 10, $107-120$.

Daft, R. L., Sormunen, J., \& Parks, D. (1988). Chief executive scanning, Environmental characteristics, and company performance: An empirical study. Strategic Management Journal, 9, 123-139.

El Mabrouki, N. M. (2007). La pratique de l'Intelligence Economique dans les grandes entreprises: voyage au cœur d'un système non univoque. Actes de la XVème Conférence Internationale de Management Stratégique. Montréal, 6-9 juin.

Feudjo, J. R., \& Tchankam, J. P. (2007). La mixité dans l'encadrement et dans la gouvernance : déterminants et impact sur la performance des entreprises au Cameroun. Acte de L'IAS.

Hall, G. (1995). Surviving and prospering in the small business sector. Londres: Routledge.

Hambrick, D. C. (1982). Environmental scanning and organizational strategy. Strategic Management Journal, 3(2), 159-174.

Hambrick D. C., \& Mason, P. A. (1984). Upper-echelons : the organization as a reflection of its top managers. Academy of Management Review, 9(2), 193-206.

Institut National de la Statistique. (2009). Rapport Général 2009, Cameroun.

Isaac, I. (2003). Utilisation d'internet pour la veille stratégique: facteur déterminant des pratiques françaises. AIMS, Grenoble, Mai, 2003.

Julien, P. A. (1994). La veille technologique. Rapport préliminaire remis au CEFRIO, Université du Québec à Trois-Rivières.

Julien, P. A. (2000). Les P.M.E. à forte croissance : les facteurs explicatifs. Actes du Congrès de l'Association Internationale de Management Stratégique. Montpellier, 24-26 Mai.

Kaish, S., \& Gilad, B. (1991). Characteristics of opportunities search of entrepreneurs versus executives: Sources, interests, general alertness. Journal of Business Venturing, 6, 45-62.

Kets de Vries, M. F. R. (2002). Combat contre l'irrationalité des managers (pp. 51-83). Edition d'Organisation.

Kombou, L. (2001). L'impact de la mondialisation des marchés sur le positionnement stratégique des entreprises camerounaises. Revue Africaine des Sciences Economiques et de Gestion, 3, 57-80.

Kombou, L., \& Feudjo, J. R. (2007). Les déterminants de la rentabilité: une étude appliquée aux valeurs culturelles ambiantes dans les industries manufacturières au Cameroun. Revue des Sciences de Gestion, (228), 45-56. 
Kriaa-Medhaffer, S. (2006). Veille anticipative stratégique, problématique de l'animation, proposition et expérimentations des connaissances actionnables situées, Cas des entreprises tunisiennes. Thèse de Doctorat en Sciences de Gestion, Université Pierre Mendes, France-Grenoble 2.

Lafaye, C. (2004). La phase de traque d'information sur Internet dans un processus de veille stratégique, une approche longitudinale centrée sur les Agents Intelligents. Thèse de Doctorat en Sciences de Gestion, Université Jean Moulin, Lyon 3, France.

Lesca, H., \& Castagnos, J. C. (2000). Signaux faibles et méthode Cible: Quelques retours d'expérience. AIMS 2000, Mai.

Lesca, H. (1994). Veille stratégique pour le management stratégique : état de la question et axes de recherche. Economie et Sociétés, 5(20), 31-50.

Lesca, H. (2003). Veille stratégique, la méthode L.E.SAning. Ed EMS, Management et Société, 190 P.

March, J. G., \& Simon, H. A. (1964). Les organisations, Paris, Dunod.

Mead, M. (1963). Mours et sexualité en Océanie. Terre humaine, Paris.

Menif, S. (2005). Problématique de la recherche d'informations d'origine «terrain » dans la Veille Stratégique: Proposition d'éléments pour la formation des traqueurs, Application aux entreprises tunisiennes. Thèse de Doctorat en Sciences de Gestion, Université Pierre Mendès-France de Grenoble CERAG CNRS UMR.

Mione et al. (2002). Comparaison des femmes entrepreneurs France-Canada. $6^{\text {ème }}$ Congrès International Francophone sur la PME-Octobre 2002-HEC-Montréal.

Montgomery, M., Johnson, T., \& Faisal, S. (2005). What kind of capital do you need to start a business: financial or human? The Quarterly Review of Economics and Finance, 45(1), 103-122. http://doi.dx.org/10.1016/j.qref.2003.11.005

Myers L.A. (1983). Information systems in research and development: the technological gatekeepers reconsidered. $R \& D$ Management, $13(4)$.

Ngongang, D. (2013). Facteurs de contingence, TIC et informations dans les entreprises tchadiennes. Revue des Sciences de Gestion, Direction et Gestion, (259-260), 153-173.

Niyungeko, P. (1993). Profil personnel, pratiques de gestion des propriétaires dirigeants et performance des PME: le cas du Burundi, Mémoire Maîtrise, Université du Québec à Chicoutin.

O'Reilly, C. A. (1982). Variations in decision maker's use of information sources: the impact of quality and accessibility of information. Academy of Management Journal, 25(4), 756-771.

Ouattara, O. (1997). La veille technologique, adaptation aux pays africains: information, environnement, moyens, culture. Thèse de Doctorat, Université de Droit, d'Economie et des Sciences d'Aix, Marseille III.

Pateyron, E. (1998). Veille stratégique. Paris: Economica,

Ramangalahy, C., Julien, P. A., Raymond, L., \& Jacod, R. (1996). Pratiques de veille technologique dans les PME manufacturières. Colloque de CCSBE-CCPME, Montréal.

Raymond, L., Bergeron, F., \& Blili, S. (2005). The assimilation of E-business in manufacturing SMEs: determinants and effects on growth and internationalization. Electronic Markets, 15(2), 106-118. http://doi.dx.org/10.1080/10196780500083761

Rim Skander, B. (2004). Etude exploratoire du profil des dirigeants des grandes entreprises privées en Tunisie : aspects sociologiques, professionnels, psychologiques et culturels. Mémoire de Master en Gestion des Organisations, Université de la Manouba, Ecole Supérieure de Commerce de Tunis.

Robidoux, J., \& Garnier, G. (1973). Facteurs de succès et faiblesses de petites et moyennes entreprises au Québec: Spécialement des entreprises utilisant des techniques de production avancées. Sherbrooke, Faculté d'Administration.

Schopenhauer, A. (2005). Essai sur les femmes. Edition Mille et une nuits, France.

Sone Mbassi, A. N. (2012). TIC, changements organisationnels et productivité des entreprises manufacturières. Revue Camerounaise de Management, (23), Janvier-Juin, Douala.

Taylor, R. N. (1975). Psychological determinants of bounded rationality: implications for decision-making. Decisions Sciences, 6, 409-429. 


\section{Notes}

Note 1. First French business intelligence firm and competitive intelligence in Africa in Dakar, Senegal. (Www.sopel.org) which organizes forums on Economic Intelligence and Development.

Note 2. This business combination was proposed by workforce by FOGAPE. Very small businesses (0-9 employees) are not part of our sample. The decision to exclude the TPE in our sample was reinforced by the work of Larivet (2002) which, following Marchesnay (1988) and Julien (2001) believes that the TPE have a particular behavior enough to constitute a category separate study in business intelligence. In addition, for Marchesnay (2003), the TPE can provide strategic paths and organizational forms significantly differentiated from other companies.

\section{Copyrights}

Copyright for this article is retained by the author(s), with first publication rights granted to the journal.

This is an open-access article distributed under the terms and conditions of the Creative Commons Attribution license (http://creativecommons.org/licenses/by/3.0/). 